\title{
TRANSITIONAL JUSTICE AND CULTURAL CONTEXTS: LEARNING FROM THE UNIVERSALITY DEBATE
}

\author{
Lieselotte Viaene and Eva Brems*
}

\begin{abstract}
Whenever a society faces the difficult process of substantial political transition after a period of gross human rights violations, the issues of justice, reconciliation, truth and reparation appear on the agenda. They form the key concepts of the emerging global paradigm of transitional justice. This booming field is faced with several unresolved and contested issues one of which is a criticism based on local and cultural particularities. In this article it is argued that it is useful to draw lessons from the universalitydiversity debate in international human rights law and confront them with local and cultural challenges that arise in the transitional justice context. It seems that the ideal of inclusiveness that remains hard to realise in human rights law, despite theoretical consensus, might have better chances of being put in practice in transitional justice initiatives.
\end{abstract}

\section{INTRODUCTION}

Whenever a society faces the difficult process of substantial political transition after a period of large-scale human rights violations, the concept of transitional justice appears on the agenda. The term 'transitional justice' is used to indicate the ways societies deal with the atrocities of the past. ${ }^{1}$ Over the past 15 years or so, transitional

Lieselotte Viaene is $\mathrm{PhD}$ researcher, Human Rights Centre, Ghent University, Belgium, lieselotteviaene@yahoo.com and Eva Brems is Professor of Human Rights Law, Human Rights Centre, Ghent University, Belgium, Eva.Brems@UGent.be. All case-law from the Inter-American Court of Human Rights referred to in this article can be consulted at: www.corteidh.or.cr and those from the European Court of Human Rights referred to in this article can be consulted in the HUDOC database at: www.echr.coe.int. All internet sources were last accessed on 21 April 2010.

1 There is no single definition of transitional justice. The Macmillan Encyclopedia of Genocide and Crimes Against Humanity states that '[t]ransitional justice refers to a field of activity and inquiry focused on how societies address legacies of past human rights abuses, mass atrocity, or other forms of severe social trauma, including genocide or civil war, in order to build a more democratic, just, 
justice has become a booming field and has gradually come to impose its concepts and frames on debates on democratisation, justice and reconstruction after the demise of authoritarian regimes. The term has been appropriated by human rights and political science scholars, as well as by the United Nations (UN) and international non-governmental organisations (NGOs). While transitional justice historically was associated with extraordinary post-conflict conditions, it has now become institutionalised, mainstreamed and normalised. ${ }^{2}$

Among scholars and practitioners of transitional justice, a consensus is emerging on its essential functions. These include accountability, truth recovery, reconciliation, reparation, guarantees of non-repetition and institutional reform as complementary and mutually reinforcing goals. Overcoming an initial polarisation between adherents of truth commissions and believers in criminal prosecution, ${ }^{3}$ current preference is for a mix of judicial and non-judicial, official and non-official strategies and approaches. Indeed, a recent UN report on the rule of law and transitional justice in conflict and post-conflict societies states that transitional justice includes both judicial and nonjudicial mechanisms, with differing levels of international involvement (or none at all) and individual prosecutions, reparations, truth-seeking, institutional reform, vetting and dismissals, or a combination thereof.' ${ }^{\prime}$ Prosecution and trials, truth commissions, vetting, institutional reform and reparation programmes are seen as tools in the transitional justice toolbox at the disposal of societies handling a legacy of atrocities. The field increasingly tends toward models for dealing with the past. At the same time, it is acknowledged that one-size-fits-all formulas are to be avoided. ${ }^{5}$ From the outset the need for contextualisation of transitional justice processes has been acknowledged, as each country in political transition has its own specific political, economical and social context.

The legal basis of transitional justice initiatives such as truth commissions or reparation programmes is currently found in national law. Yet an international legal framework for transitional justice is increasingly taking shape. The most prominent example of hard international law in this field is the Statute of the International Criminal Court (ICC), established to prosecute war crimes, genocide and crimes

or peaceful future'; Macmillen Reference USA, Vol. 3, 2004, pp. 1045-1047. Key references are: Kritz, Neil (ed.), Transitional Justice: How Emerging Democracies Reckon with Former Regimes, US Institute of Peace, Washington DC, 1995, Vols I-III; Mendez, Juan, 'Accountability for Past Abuses', Human Rights Quarterly, Vol. 19, No. 2, 1997, pp. 225-282; and Teitel, Ruti, Transitional Justice, Oxford University Press, Oxford, 2002.

2 Teitel, Ruti, 'Transitional Justice Genealogy', Harvard Human Rights Journal, Vol. 16, Spring 2003, pp. 69-94, at p. 69.

3 Roth-Arriaza, Naomi, 'The New Landscape of Transitional Justice', in: Roth-Arriaza, Naomi and Mariezcurrena, Javier (eds), Transitional Justice in the Twenty-First Century: Beyond Truth Versus Justice, Cambridge University Press, Cambridge, 2006, pp. 1-16.

4 The Rule of Law and Transitional Justice in Conflict and Post-Conflict Societies: Report of the Secretary-General, UN Doc. S/2004/616, 23 August 2004, at p. 4.

5 Idem. 
against humanity under international law. Another sign of the translation of transitional justice experiences and models into international law - as yet still 'soft law' -, is the UN declaration of basic principles and guidelines on the right to a remedy and reparation for victims of gross human rights violations. ${ }^{6}$ In addition, both the Inter-American Court of Human Rights ${ }^{7}$ and the European Court of Human Rights, ${ }^{8}$ have addressed allegations of human rights violations in a transitional justice context. This growing body of case-law also contributes to the normative development of transitional justice in international law. A clear example of this development is the 'right to truth' as an emerging rule of international law. ${ }^{9}$ It is to be expected that this tendency to develop the normative component of transitional justice and to root it in international human rights law, will expand in the near future.

Given the enormous proliferation of norms setting out international human rights standards, the need to add clear rules stipulating appropriate remedies in case of violations of those standards is felt. Arguably, rules setting out how to deal with a legacy of widespread and gross violations may be seen as a priority in this field.

The emergence of a global paradigm of transitional justice and its increasing legal embedment however do not do away with a host of unresolved and contested issues. These concern for example real or perceived tensions between justice and peace, or between truth and accountability. The nexus between transitional justice and development requires clarification, and the professed need to engender transitional justice has not yet been developed in all transitional justice tools. This article addresses another challenge to the emerging paradigm of transitional justice; one that is based on cultural diversity. The rise of global models of transitional justice is increasingly met with a criticism based on local and cultural particularities. The involvement of international actors in transitional justice efforts strengthens perceptions that Western models are being imposed or at least promoted in non-Western contexts. Empirical

$6 \quad$ Basic Principles and Guidelines on the Right to a Remedy and Reparation for Victims of Gross Violations of International Human Rights Law and Serious Violations of International Humanitarian Law: Resolution Adopted by the General Assembly, UN Doc. A/Res/60/147, 21 March 2006.

7 For example Inter-American Court of Human Rights, Myrna Mack Chang vs Guatemala, 25 November 2003, IACHR database (www.corteidh.or.cr); Maritza Urrutia vs Guatemala, 27 November 2003, IACHR database; Plan de Sánchez Massacre vs Guatemala, 29 April 2004, IACHR database; and Escué-Zapata vs Colombia, 4 July 2007, IACHR database.

8 For example European Court of Human Rights, K-H W vs Germany vs Germany, 22 March 2001, Application No. 37201/87, HUDOC database (www.echr.coe.int); Streletz, Kessler en Krenz vs Germany, 22 March 2001, Application Nos 34044/96, 35532/97 and 44801/98, HUDOC database; Velikovi and others vs Bulgaria, 15 March 2007, Application Nos 43278/98, 45437/99, 48380/99, 48014/99, 51362/99, 53367/99, 60036/00, 73465/01 and 194/02, HUDOC database; Pincová and Pinc vs Czech Republic, 5 November 2002, Application No. 36548/97, HUDOC database; Viaşu vs Romania, 9 December 2008, Application No. 75951/01, HUDOC database; Matyjek vs Poland, 24 April 2007, Application No. 38184/03, HUDOC database; and Ấdamsons vs Latvia, 24 June 2008, Application No. 3669/03, HUDOC database.

9 E.g. Inter-American Court of Human Rights, Trujillo-Oroza vs Bolivia, 27 February 2002, IACHR database (www.corteidh.or.cr). 
field research shows the existence of culture-based views on justice, reconciliation, truth and reparation that differ fundamentally from mainstream interpretations. These 'local' and 'cultural' challenges will need to be addressed by transitional justice scholars and practitioners. In this article, it is argued that they can draw useful lessons from the universality-diversity debate in international human rights law. Obviously the issues are not quite the same: transitional justice might be seen as secondary to human rights, as it is about dealing with human rights violations that have been acknowledged. A cultural critique contesting the finding of a violation is of a different nature than one challenging the appropriate way to address that violation. Yet the cultural diversity claims one encounters reveal significant thematic similarities, for example the issue of individualism versus community values. Moreover, the cultural and political context from which they originate is also similar, as 'pragmatic' arguments of local relevance interlock with 'principled' arguments of cultural authenticity. In the light of these parallels, it is useful to draw some lessons from the universalitydiversity debate in international human rights discourse (section 2), and confront them with the cultural challenges that arise in a transitional justice context (section 3). It seems that the ideal of inclusiveness that remains hard to realise in human rights law, despite theoretical consensus, might have better chances of being put in practice in transitional justice initiatives.

\section{AVOIDING A SEQUEL TO THE UNIVERSALISM- RELATIVISM DEADLOCK}

Human rights scholars and activists have long been familiar with culture-based challenges to the relevance and adequacy of 'Western' human rights in non-Western societies. It should not come as a surprise that similar challenges are now confronting the emerging field of transitional justice. Transitional justice is strongly linked to human rights, as it concerns the way a society deals with gross human rights violations of the past. Moreover, human rights increasingly function as a framework for transitional measures, as is demonstrated by the European and Inter-American case-law cited above. Moreover, human rights standards establish the obligation to bring perpetrators of human rights violations to justice and to provide reparation to victims. ${ }^{10}$ Even though human rights law does not provide answers to many of the questions raised by transitional justice practice - as these have strong political, moral and social dimensions - 'transition' is becoming a concept of human rights law. ${ }^{11}$

10 Human Rights Committee, General Comment No. 31 'The Nature of the General Legal Obligation Imposed on States Parties to the Covenant', UN Doc. CCPR/C/21/Rev.1/Add.13, 26 May 2004, paras $16-18$.

11 Marton, Varju, 'Transition as a Concept of European Human Rights Law', European Human Rights Law Review, No. 2, 2009, pp. 170-189, at p. 170. 
Hence, human rights lawyers naturally move occasionally into transitional justice, and transitional justice practicioners at times have to address human rights concerns. This section will explore the comparability of the two debates, as well as the main insights that can be gained from several decades of debating cultural difference in the human rights context.

\subsection{COMPARING STARTING POSITIONS: TRANSITIONAL JUSTICE VERSUS HUMAN RIGHTS}

Confronted with allegations of Western bias and with claims for the accommodation of cultural diversity, transitional justice compared to human rights brings better cards to the table.

In the first place, Western dominance is less pronounced in transitional justice. This is related to the context in which the transitional justice paradigm is emerging. The normative dimension of transitional justice remains modest; and the models that are being promoted are based on field practice that is largely concentrated in the South. For example, the transitional justice flagship model of the 'truth commission' did not originate in the West, but took shape in Latin America and South Africa. It can thus not be claimed that transitional justice is based solely on Western models and concepts. In the area of human rights on the other hand, both the idea of a right as an enforceable claim upon a duty holder, and the format of a list of rights supposedly corresponding to a common human nature, are historically and conceptually Western. Moreover the adoption of the Universal Declaration of Human Rights - mother text of international human rights law - in 1948 took place in a context when most of the Southern hemisphere was under colonial domination by the North. In today's world, dominance of the West/North remains strong, yet the rise of the BRIC countries ${ }^{12}$ is the mantra of the day and spokespersons of non-Western societies - Islamic countries amongst others - assertively defend their culturally inspired worldviews in international fora. In comparison to international human rights, the impact of Western bias on transitional justice is significantly attenuated.

In the second place, the stake is lighter for both sides in the debate when it concerns transitional justice, enhancing the potential for compromise. Cultural diversity claims in transitional justice do not in the least intend to question the utter unacceptability of the gross human rights violations that happened in the past. The discussion concerns merely the reaction to those violations. Whereas cultural claims questioning the qualification of certain entitlements as human rights or of certain behaviour as a human rights violation have been interpreted by defendants of the dominant international model as threats that risk undermining the universality of human rights, claims that are restricted to remedies need not raise similar concern.

12 Brazil, Russia, India and China. 
A consensus on universal norms need not necessarily be accompanied by universally prescribed reactions to violations of those norms.

Another factor concerns the authors of cultural specificity claims or critiques. In the human rights debates, criticism is voiced in both academic and political fora by authors who are both insiders and outsiders of the cultures concerned. By comparison, the cultural critique in transitional justice is mostly of outsider, academic origin. While this may create issues of legitimacy - but so does an insider discourse that is largely elite-based - it also has the advantage of academic serenity. While academic criticism can be fierce, it remains rational and well argued, which offers significantly better prospects for constructive outcomes than many of the political debates that have taken place on issues opposing 'the West' and 'the rest'.

Finally, the fact that international law on transitional justice is still being developed, offers the opportunity to integrate cultural diversity and flexibility from the outset. Moreover, any norms on transitional justice necessarily provide for contextualisation, as transitional justice is conceived as a response to a particular abusive past in a specific society. In transitional justice, the need for contextualisation is widely recognised. The challenge then consists of recognising an additional contextual dimension, that is the cultural dimension. In contrast, the iusnaturalist origins of human rights create obstacles to contextualisation per se, with their reference to a mythical 'essential human'. Also, when making the case for contextual flexibility (cf. infra section 2.2.) with respect to norms that have not been drafted for that purpose, one encounters other hurdles, such as dependence on interpreters (judges, policy makers and others) willing to 'see' the room for diversity, and ideological resistance to activist jurisprudence. The a priori awareness that contextual accommodation is necessary in transitional justice is therefore an invaluable asset, as it allows norm makers to integrate this concern explicitly in the norms. While both the urgency and the opportunity to do this are there, the political will however remains to be secured.

\subsection{LESSONS LEARNED: HOW FAR HAVE WE GOT IN THE HUMAN RIGHTS/CULTURAL DIVERSITY DEBATE?}

In addition to the advantageous starting position described above, another important reason why it should be easier to address cultural diversity claims in respect of transitional justice than in relation to human rights, is the fact that the more recent debate on transitional justice can benefit from the lessons learned during several decades of debate on the universality and/or cultural relativity of human rights.

\subsubsection{Principle: Betweenness and Hybridity}

In human rights mythology as well as in some of the literature, the latter debate is presented as a trench war between 'universalists' and 'relativists'. Universalists are 
defenders of uniform human rights throughout the world, based on a belief in the commonality of human nature and human needs - whereas cultural relativists reject the idea of universal human rights, because they see human rights as a Western construct that cannot have any validity in non-Western societies. While this framing makes for an excellent starting point for classroom discussions, it holds human rights hostage in a deadlock that appears impossible to resolve. This leads to the conclusion that cultural relativism needs to be defeated so as to enable human rights to spread throughout the world.

This black-and-white picture is a distortion of a debate that in reality is much more nuanced. The - Western - anthropologists who coined the term 'cultural relativism' in the first half of the $20^{\text {th }}$ century may well have recognised themselves in the above description. Yet their views have few if any adherents among contemporary anthropologists. ${ }^{13}$ The term 'cultural relativism' has frequently been extended from this anthropological context to the discourses of representatives of non-Western societies in both political and academic fora accusing human rights of Western bias. This is misleading, as an analysis of contemporary non-Western particularist critiques of human rights reveals at least two fundamental differences with 'classical' cultural relativism. First and foremost, these critics do not reject the idea of human rights, but rather question their concrete shape, their interpretation and application, as well as political choices and actions taken in the name of human rights. By claiming the validity of alternative 'non-Western' views of human rights, they may be attacking dominant interpretations of human rights, but at the same time they express support for or at least acceptance of the concept of human rights. In addition, non-Western particularist critiques are rarely based on cultural difference alone. As arguments of economic and political specificities are intertwined with arguments of cultural diversity, their central claim is best described as promoting the contextualisation of human rights.

At the same time, proponents of universal human rights have realised that, if one sets aside abusive use of the particularist discourse by authoritarian governments trying to fend off international scrutiny of their human rights record, promoters of contextualism have a point. Sixty years after the adoption of the Universal Declaration of Human Rights, human rights hold a sufficiently strong position for their proponents to be able to admit to shortcomings. One of these is the fact that efforts to model human rights on an abstract human being are inevitably prone to distortion. It is now generally realised that the impossibility of a neutral vantage point from which to picture this abstract human being, has lead to human rights being tailored largely

13 Cf. the replacement of the famous relativist anti-human rights statement of the American Anthropological Association by a new statement adopted in 1999: American Anthropological Association, 'Statement on Human Rights', American Anthropologist, Vol. 49, No. 4, 1947, pp. 539543, reprinted in: Winston, Morton E. (ed.), The Philosophy of Human Rights, Wadsworth, Belmont, 1989, pp. 116-120; and American Anthropological Association, 'Declaration on Anthropology and Human Rights', 1999, at: www.aaanet.org/stmts/humanrts.htm. 
to the dominant human being: one who is adult, male, heterosexual, not disabled and Western. Several non-dominant groups have successfully campaigned for new additions to or interpretations of human rights standards that would redress such imbalances. ${ }^{14}$ Likewise, the relevance of taking into account the societal context in human rights is now recognised both in theory and in practice, even if many unresolved issues remain.

In the literature, the crucial insight is that universal human rights can accommodate cultural and other contextual differences; it is not an either/or issue: we can promote universal human rights and respect diversity at the same time. Universality does not require uniformity. A consensus has emerged in the literature on this issue, even though each author uses his or her own terminology and phrasing to express it. It is particularly interesting to find that across academic disciplines, similar conclusions are reached through different methodologies. Roughly, a distinction can be made between authors who have examined the issue in a top-down manner and others who have used a bottom-up approach. The former, mainly lawyers and political scientists have taken international human rights standards and the international human rights protection system as a starting point and have argued that it is both desirable and feasible to integrate contextual diversity within those. Donnelly, one of the leading voices in this debate, has long defended 'weak cultural relativism'. ${ }^{15}$ More recently, he proposed the concept of 'relative universality of human rights' to express the view that 'universal human rights, properly understood, leave considerable space for national, regional, cultural particularity and other forms of diversity and relativity'. ${ }^{16}$ Brems has used the term 'inclusive universality', emphasising that the accommodation of contextual factors is intended to remedy the exclusion experienced by people who do not correspond to the implicit reference point of human rights.

The exclusion consists of the fact that the needs, concerns and values of members of nondominant groups are not taken into account to the same extent as those of the members of dominant groups when human rights standards are formulated or interpreted, and when human rights policies are determined. Inclusive universality proposes to remedy this situation by accommodating particularist claims from those excluded people. ${ }^{17}$

14 In addition to the spectacular successes of women's human rights groups in putting issues such as domestic violence, sexual violence and reproductive rights on the agenda, other groups have sought inclusion of their specific concerns through group-specific instruments, such as the Convention on the Rights of the Child (1989) and the Convention on the Rights of Persons with Disabilities (2006).

15 Donnelly, Jack, 'Cultural Relativism and Universal Human Rights', Human Rights Quarterly, Vol. 6, No. 4, 1984, pp. 400-419.

16 Donnelly, Jack, 'The Relative Universality of Human Rights', Human Rights Quarterly, Vol. 29 , No. 2, 2007, pp. 281-306, at p. 281.

17 Brems, Eva, 'Reconciling Universality and Diversity in International Human Rights: A Theoretical and Methodological Framework and Its Application in the Context of Islam', Human Rights Review, Vol. 5, No. 3, 2004, pp. 5-21, at pp. 11-12. 
Others prefer to talk about 'a pluralist conception of human rights', conceived as a combination of common leading principles with a national margin of appreciation in recognition of a right to be different. ${ }^{18}$

At the same time, those examining human rights in action in the field - mainly anthropologists - have described how local communities instrumentalise and adapt human rights discourses, norms and procedures in their quest for justice and fairness, and have argued the value and legitimacy of such 'vernacularisation'19 or 'localisation' 20 of human rights. It is stated that 'human rights is an open text, capable of appropriation and redefinition by groups who are players in the global legal arena'. ${ }^{21}$ Goodale has situated human rights 'between the global and the local', in an intentionally open conceptual space which can account for the way actors encounter the idea of human rights through the projection of the legal and moral imagination'. ${ }^{22}$ Hellum has used the term 'cultural pluralism' to describe the space 'between universalism and relativism as well as individualism and communalism'23 where human rights and non-Western cultures can be reconciled.

Crucial learnings from anthropology have gradually been integrated in legal and political debates on human rights and cultural diversity. The main point of those is that representations of culture as static and homogenous cannot hold. Anthropology uses a far more sophisticated and complex concept of culture:

Over the last two decades, anthropology has elaborated a conception of culture as unbounded, contested, and connected to relations of power. (...) Its boundaries are fluid, meanings are contested, and meaning is produced by institutional arrangements and political economy. Culture is marked by hybridity and creolization rather than uniformity

18 Cohen-Jonathan, Gérard, 'Universalité et singularité des droits de l'homme' [Universality and singularity of human rights], Revue Trimestrielle des Droits de l'Homme, 53, 2003, pp. 1-13, at p. 11; and Delmas-Marty, Mireille,'De la juste dénomination des droits de l'homme' [On the right denomination of human rights], Droit et Cultures, Vol. 35, 1998, pp. 105-116.

19 Merry, Sally Engle, 'Legal Pluralism and Transnational Culture: The Ka Ho'okolokolonui Kanaka Maoli Tribunal, Hawai'i, 1993', in: Wilson, Richard (ed.), Human Rights, Culture \& Contest; Anthropological Perspectives, Pluto Press, London, 1997, pp. 28-48, at p. 29. Merry, Sally Engle, 'Transnational Human Rights and Local Activism: Mapping the Middle', American Anthropology, Vol. 108, No. 1, 2006, pp. 38-51.

20 De Feyter, Koen, 'Localizing Human Rights', Discussion paper, Institute of Development Policy and Management, Antwerp University, 2006, available at: www.ua.ac.be/objs/00152976.pdf.

21 See Merry, 'Legal Pluralism and Transnational Culture: The Ka Ho'okolokolonui Kanaka Maoli Tribunal, Hawai'i, 1993', loc.cit. (note 19), at p. 30.

22 Goodale, Mark, 'Locating rights, envisioning law between the global and the local', in: Goodale, Mark and Merry, Sally Engle (eds), The Practice of Human Rights; Tracking Law Between the Global and the Local, Cambridge University Press, Cambridge, 2007, pp. 1-38, at p. 22.

23 Hellum, Anne, 'Women's Human Rights and African Customary Laws: Between Universalism and Relativism - Individualism and Communitarianism', in: Lund, Christian (ed.), Development and Rights; Negotiating Justice in Changing Societies, Routledge, Oxford, 1999, pp. 88-104, at p. 96. 
or consistency. Local systems are analyzed in the context of national and transnational processes and are understood as the result of particular historical trajectories. ${ }^{24}$

In this light, mainstream human rights views of culture as 'a barrier to the reformist project of universal human rights ${ }^{25}$ soon reveal themselves as overly simplistic. Merry has provided the vital insight that 'recognizing the extent to which the human rights project is itself a cultural one, and that it can build upon culture rather than only resist it, would foster its expansion and use by local activists'. ${ }^{26}$ Indeed, many in the mainstream human rights world have now come to the conclusion that the accommodation of cultural diversity is key to strengthening the universality of human rights as a real factor for the good in people's lives - as opposed to a mere theoretical construct. What is more, the continuing tension between the uniformising tendencies inherent in universalism and the vocal - at times assertive or even aggressive - claims for contextualisation and diversity need not be a cause for alarm or even be identified as a problem. Rather it should be seen 'as part of the continuous process of negotiating ever-changing and interrelated global and local norms'. ${ }^{27}$ Rather than bemoaning this tension, or trying to ignore it, human rights must recognise it and deal with it.

\subsubsection{Practice: Dialogue and Flexibility}

The theoretical breakthrough in transcending the universalism-relativism deadlock has not been matched by equal success in the practice of contextualising human rights standards. Yet important progress has been made nevertheless. We list some of the main breakthroughs.

One view on how to deal with diversity claims in human rights that seems to gather wide support, is An-Na'im's emphasis on dialogue. ${ }^{28}$ Several dialogues need to be conducted. Dialogues within societies are needed to allow both the contextualisation of human rights and the reinterpretation of cultural rules and practices in the light of human rights. And dialogues between societies are needed to reach agreement on the nature and extent of contextualisation that is acceptable within a universal human rights framework. Both dialogues strengthen local ownership and legitimacy of human rights.

$24 \quad$ Merry, Sally Engle, 'Human Rights Law and the Demonization of Culture (And Anthropology Along the Way)', Political and Legal Anthropology Review, Vol. 26, No. 1, 2003, pp. 55-76, at p. 67.

Ibidem, at p. 72 .

Idem.

Cowan, Jane K., Dembour, Marie-Bénédicte and Wilson, Richard A., 'Introduction', in: Cowan, Jane K., Dembour, Marie-Bénédicte and Wilson, Richard A. (eds), Culture and Rights: Anthropological Perspectives, Cambridge University Press, Cambridge, 2001, pp. 1-26, at p. 6.

28 An-Na'im, A.A. (ed.), Human Rights in Cross-Cultural Perspectives: a Quest for Consensus, University of Pennsylvania Press, Pennsylvania, 1991, pp. 4-5. 
Expectations and agendas for a dialogue among civilisations are sometimes set unrealistically high, when it is assumed that an agreement should extend not only to human rights standards, but also to their underlying foundations. Several influential authors now defend the position that a human rights system based on an 'overlapping consensus' of foundations that are each rooted in the context of a society, may be stronger than a system that purports to derive its legitimacy from a single - necessarily contested - foundation. ${ }^{29}$ This is based on the finding that in practice, despite the lack of consensus over the foundation of human rights, the consensus surrounding the validity of human rights is overwhelming. This consensus is based on non-universal foundations: 'human rights has gone global by going local'. ${ }^{30}$ Borrowing from Walzer, ${ }^{31}$ Chan has argued that thick accounts of human rights have to be developed from inside societies, grounded in the society's political morality, whereas outsider condemnations of human rights violations need to adopt a thin account, of minimal universalistic human rights terms. ${ }^{32}$

Another aspect that is widely promoted, is the integration of a measure of flexibility in human rights standards. Donnelly distinguishes between human rights concepts, conceptions and implementation. ${ }^{33}$ Diversity is not needed at the level of the broad formulations that make up rights concepts. Yet each concept has multiple defensible conceptions, and any particular conception has many possible implementations. At the latter level, diversity of contextualised solutions is not merely defensible but desirable. As broad as the agreement on the need to leave room for contextualisation, is the consensus that such room should not be unlimited. A lot of the discourse on this topic refers to the untouchability of an - as yet undefined - hard core or essential substance of human rights. ${ }^{34}$

Somewhat more contested, several authors adopt the position that even though an emphasis on communalism over individualism is one of the main themes in nonWestern diversity claims, individual autonomy should be central in a human rights approach to diversity. This implies that groups are not allowed to impose restrictive rules on dissident members, and that the human rights system should support the

29 See Gutmann, Amy, 'Introduction', in: Ignatieff, Michael (ed.), Human Rights as Politics and Idolatry, Princeton University Press, Princeton, 2001, pp. vii-xxviii, at pp. xviii-xix. See also Appiah, K. Anthony, 'Grounding Human Rights', in the same volume, pp. 101-116 and Ignatieff, Michael, 'Human rights as Polics and Human Rights as Idolatry', also in the same volume, pp. 3-100.

30 Appiah, loc.cit. (note 29), p. 106, borrowing the quotation from Ignatieff.

31 Walzer, Michael, Thick and Thin. Moral argument at home and abroad, University of Notre Dam Press, Notre Dame, 1994.

32 Chan, Joseph, 'Thick and Thin Accounts of Human Rights - Lessons from the Asian Values Debate', in: Ryden, Edmund (ed.), Human Rights and Values in East Asia. Proceedings of the Fujen International Conference on Human Rights and values in East Asia, Fujen Catholic University, John Paul II Institute for Research into dialogue for Peace, Taipei, 1998, pp. 45-63.

33 Donnelly, loc.cit. (note 16), at p. 299.

34 See Cohen-Jonathan, loc.cit. (note 18), at p. 11. 
'right to opt out' of the latter. ${ }^{35}$ In a similar vein, Brems has suggested the insider perspective of the (potential) victim of human rights violations as a methodological tool to deal with diversity in human rights. ${ }^{36}$

Among lawyers, some work has been done to show how existing legal flexibility tools can be used to accommodate contextual diversity in human rights. In the area of children's rights for example, it has been argued that the central criterion of the 'best interest of the child' (Article 3(1) Convention on the Rights of the Child (CRC)) exemplifies elastic language that offers 'enormous scope' for cultural difference to be taken into account in the implementation of CRC norms at the domestic level. ${ }^{37}$

In addition to the contextual interpretation of elastic provisions or vague and general concepts, it has been suggested that the 'margin of appreciation doctrine'38 and the rule of progressive realisation ${ }^{39}$ might be developed into valuable tools for the accommodation of contextual factors. The margin of appreciation frames the room for domestic variation among the 47 member States of the European Convention on Human Rights. As applied by the European Court of Human Rights, it explicitly takes cultural and religious sensitivities into account. While is not uncontested and far from a full-fledged doctrine, it offers a useful basis on which to build a tool that can be transposed to the universal level. Progressive realisation is a flexibility tool that is currently limited to economic diversity and to the area of economic, social and cultural rights. Brems has argued that it is worth considering extending this tool to other types of diversity and to all human rights.

Contextualising human rights remains a hotly debated challenge in many fields. Yet at the same time it is happening, not only in the discourse and practice of local actors as described by anthropologists, but also in the work of regional and domestic human rights monitoring bodies. The African Charter on Human and Peoples' Rights is famous for its deliberate 'Africanisation' of human rights, including both collective rights and individual duties, such as the duty to respect one's parents (Article 29(1)). The Inter-American Court of Human Rights has integrated cultural context in its interpretation, in particular when dealing with indigenous peoples.

35 Howard, Rhoda E., Human Rights in Commonwealth Africa, Rowman \& Littlefield Publishers, Totowa, 1986, pp. 198-200.

36 Brems, Eva, Human Rights: Universality and Diversity, Martinus Nijhoff Publishers, Leiden/Boston, 2001, p. 323.

37 Alston, Philip, 'The best interests principle: towards a reconciliation of culture and human rights', in: Alston, Philip (ed.), The Best Interests of the Child: Reconciling Culture and Human Rights, Clarendon Press, Oxford, 1994, pp. 1-25, at p. 19.

38 Brems, Eva, 'The Margin of Appreciation Doctrine of the European Court of Human Rights: Accommodating Diversity within Europe', in: Forsythe, David P. and McMahon, Patrice C. (eds), Human Rights and Diversity: Area Studies Revisited, University of Nebraska Press, Lincoln/London, 2003, pp. 81-110.

39 Brems, Eva, 'Accommodating Diversity in International Human Rights: Legal Techniques', in: Meerts, Paul (ed.), Culture and International Law, Hague Academic Press, The Hague, 2008, pp. $63-81$. 
In the Awas Tingni Case, it found amongst others a violation of property rights due to the exploitation of the territories of an indigenous people. The Court interpreted the property right in the Inter-American Convention in a novel way, integrating both a collective component and a spiritual dimension. ${ }^{40}$ At the domestic level, the Constitutional Court of Colombia went so far as to qualify corporal punishment (lashes on the legs) practiced by an indigenous people as falling outside the scope of torture or 'inhuman or degrading punishment' on account of its cultural meaning. ${ }^{41}$ In other cases, domestic bodies have used the space between the local and the global to re-interpret cultural norms in the light of human rights. An inspiring example is the Bhè ruling of the Constitutional Court of South Africa. ${ }^{42}$ In this case, the rule of male primogeniture in codified customary inheritance law was overruled in the light of constitutional provisions on gender equality, based on an argument of cultural dynamism: the Court contrasted 'official' customary law with 'living' customary law that adapted to fit changing circumstances, and consecrated the latter.

\section{CULTURAL CHALLENGES TO TRANSITIONAL JUSTICE IN THE FIELD}

In transitional justice, cultural challenges are part of a critical evaluation and reflection that is going on as part of the maturation process of the field. One of the outcomes of this process is the growing awareness among transitional justice scholars that the transitional justice template is highly abstract, general, legalistic and top-down. In a significant pendulum motion, academic thinking currently swings toward bottomup, interdisciplinary, empirical and concrete approaches.

\subsection{SHIFTING LENSES}

Currently, several trends may be distinguished in the academic literature that coincide in their attempts to re-orient the transitional justice field.

A first point of critique concerns the dominance of legal discourse, despite the origins of the field in political studies of regimes in democratic transition. It is argued that 'a narrow, legalistic lens (...) impedes both scholarship and praxis'. ${ }^{43}$ Instead,

40 Inter-American Court of Human Rights, Mayagna (Sumo) Awas Tingni Community vs Nicaragua, Judgment of 31 August 2001, IACHR database (www.corteidh.or.cr).

41 Constitutional Court of Colombia, T-523, 15 October 1997, confirmed in T-934 (1999), www. corteconstitucional.gov.co/.

42 Constitutional Court of South Africa, Bhè and others, case CCT 50/03, 15 October 2004, www. constitutionalcourt.org.za/.

43 McEvoy, Kieran, 'Letting Go of Legalism: Developing a “Thicker" Version of Transitional Justice', in: McEvoy, Kieran and McGregor, Lorna (eds), Transitional Justice from Below. Grassroots Activism and the Struggle for Change, Hart Publishing, Oxford, 2008, pp. 15-45. 
McEvoy calls upon lawyers in the field to develop a 'thicker version of transitional justice' and to 'let go of legalism'. This implies the recognition of the limitations of a legal approach and a greater willingness to give space to other actors apart from State or 'State-like' institutions as well as to insights from other disciplines and forms of knowledge.

Second, there is a trend in academic thinking and in the international community to move away from the 'one size-fits-all' approach to transitional justice. ${ }^{44}$ 'Given the extraordinary range of national experiences and cultures, how could anyone imagine there to be a universally relevant formula for transitional justice? ${ }^{45}$ A consensus has emerged in favour of broadening the scope of transitional justice to local approaches. Concepts that are gaining currency in recent debates include 'transitional justice from below', 'local approach', 'bottom-up', 'macro-micro', and 'local ownership'. ${ }^{46}$

Third, inherently related with this is the emerging recognition of the need to take into account the expectations of the affected people in all stages of transitional justice policies - conceptualisation, design, implementation and management. ${ }^{47}$ The underlying premise is that a transitional justice process should respond to the needs of the survivors. Nevertheless, it remains rare to find empirical studies that base policy recommendations on consultations of future beneficiaries or that evaluate transitional justice efforts - such as reparations programmes, truth commissions or trials - in the light of survivors' needs and preferences. ${ }^{48}$ Several suggestions have been made to improve responsiveness of transitional justice processes. Pham and Vinck propose 'evidence-based transitional justice' based on systematic monitoring

44 See The Rule of Law and Transitional Justice in Conflict and Post-Conflict Societies: Report of the Secretary-General, supra note 4.

45 Orentlicher, Diane, 'Settling Accounts Revisited: Reconciling Global Norms with Local Agency', International Journal of Transitional Justice, Vol. 1, No. 1, 2007, pp. 10-22, at p. 18.

46 See United Nations Assembly, The Nuremberg Declaration on Peace and Justice, UN Doc. A/62/885, 19 June 2008, outcome of the International Conference 'Building a Future on Peace and Justice', Nuremberg, Germany, June 2007. McEvoy, Kieran and McGregor, Lorna, 'Transitional justice From Below: An Agenda for Research, Policy and Praxis', in: McEvoy and McGregor (eds), op.cit. (note 43), pp. 1-13; Pouligny, Béatrice, Chesterman, Simon and Schnabel, Albrecht, 'Introduction: Picking up the pieces', in: Pouligny, Béatrice, Chesterman, Simon and Schnabel, Albrecht (eds), After Mass Crime. Rebuilding States and Communities, United Nations University Press, Tokyo, 2008, pp. 1-16; and International Conference Oxford Transitional Justice Research, 'Taking at Stock Transitional Justice', University of Oxford, Oxford, June 2009.

47 See The Rule of Law and Transitional Justice in Conflict and Post-Conflict Societies: Report of the Secretary-General, supra note 4; Orentlicher, loc.cit. (note 45); and Lundy, Patricia and McGovern, Mark, 'The Role of Community in Participatory Transitional Justice', in: McEvoy and McGregor (eds), op.cit. (note 43), pp. 99-120.

48 The Redress Trust, 'Torture Survivors' Perceptions of Reparation: Preliminary Survey',2001, available at: www.redress.org/publications/TSPR.pdf. Due Process of Law Foundation, 'Después de procesos de justicia transicional ¿Cuál es la situación de las víctimas?’ [After transitional justice processes. What is the situation of the victims?], 2007, available at: www.dplf.org/uploads/1225809541.pdf. 
and evaluation of the context and impact of interventions. ${ }^{49}$ Shaw on the other hand considers ethnographic research to be the most appropriate approach, because it seeks to understand processes, events and ideas on the people's own terms and thus makes a powerful tool for challenging received wisdom and for understanding events and processes on the ground. ${ }^{50}$

A fourth tendency, which is often intertwined with the third, is the idea of using traditional and informal justice systems and revisiting traditional and local culture as a means of dealing with the legacy of gross human rights violations. Koffi Annan, then UN secretary-general, officially acknowledged that 'due regard must be given to indigenous and informal traditions for administrating justice or settling disputes, to help them to continue their vital role and to do so in conformity with both international standards and local tradition. ${ }^{51}$ This trend has its roots in a number of experiences with the mobilisation of traditional approaches to justice and reconciliation into transitional justice strategies. The most well-known examples are the Gacaca tribunals in Rwanda, the use of mato oput rituals, part of the Acholi justice system in northern Uganda and the incorporation of traditional leaders in the truth and reconciliation commissions in Sierra Leone and Timor-Leste. International non-governmental organisations and donor countries have supported those traditional justice instruments and 'a hype was born'. ${ }^{52}$ Yet its impact should not be overstated. Discussions on the role of traditional mechanisms in transitional justice are mainly located in Sub-Saharan Africa. Debates on Rwanda and Northern Uganda moreover polarise between scholars and practitioners 'in favour' and those opposed. Finally, there is a gap between rhetoric and reality. It has been remarked that '[i]t is commonplace to hear that culture and context "matter", and that any intervention -

49 Phuong, Pham and Vinck, Patrick, 'Empirical Research and the Development and Assessment of Transitional Justice Mechanisms', International Journal of Transitional Justice, Vol. 1, No. 1, 2007, pp. 231-248.

50 See Shaw, Rosalind, Rethinking Truth and Reconciliation Commissions. Lessons from Sierra Leon, United States Institute of Peace Special Report, Washington DC, 2005; and Shaw, Rosalind, 'Memory Frictions: Localizing the Truth and Reconciliation Commission in Sierra Leone', International Journal of Transitional Justice, Vol. 1, No. 2, 2007, pp. 183-207, at pp. 187-189. Theidon equally argues that an ethnographic approach allows studying sensitive topics and subjective processes in a climate a great distrust, whereas the utility of surveys is limited in these contexts; Theidon, Kimberly, 'Transitional Subjects: The Disarmament, Demobilization and Reintegration of Former Combatants in Colombia', International Journal of Transitional Justice, Vol. 1, No. 1, 2007, pp. 6690.

51 See The Rule of Law and Transitional Justice in Conflict and Post-Conflict Societies: Report of the Secretary-General, supra note 4.

52 Huyse, Luc, 'Introduction: tradition-based approaches in peacemaking, transitional justice and reconciliation policies', in: Huyse, Luc and Salter, Mark (eds), Traditional Justice and Reconciliation after Violent Conflict. Learning from African Experiences, IDEA, Stockholm, 2008, pp. 1-24, at p. 1. 
peace-building or otherwise - must be "culturally sensitive". This has been truer of rhetoric than reality. ${ }^{53}$

\subsection{THEORY: FROM TERMINOLOGY TO SUBSTANCE}

The integration of local/traditional views and mechanisms in transitional justice is not uncontested. Some of the debates appear to centre on the qualification of certain practices as 'traditional' and on the meaning of that term. This is related to the Rwandan experiment that officialised and adapted a traditional dispute resolution mechanism (Gacaca). Many have questioned how much 'tradition' is left in the 'modern and new' Gacaca jurisdictions. ${ }^{54}$ A recent study, examining the role of traditional justice mechanisms in five post-conflict countries in Africa, put forward the notion of 'tradition-based practices'. ${ }^{55}$ The authors explicitly acknowledge the dynamic processes that drive the form and content of those practices. Yet they continue to struggle with the concept as they clarify 'all indigenous justice and reconciliation practices are, strictly speaking, no longer traditional. But some are newer than others. ${ }^{56}$ Some field researchers avoid the term 'traditional justice', which they consider to have an inherent essentialist connotation. In order to move beyond the polarised debate between 'modern' and 'traditional', they choose to employ the concept of local approaches or local justice. ${ }^{57}$ Other terms such as customary, informal, and indigenous justice systems also appear in empirical research. The present authors prefer a reference to 'local and cultural practices and attitudes'. This phrase bypasses the - largely irrelevant - debates on what is traditional and what not, and is broad enough to encompass a wide range of phenomena.

Contemporary anthropological views on the dynamic and hybrid character of culture and tradition (cf. supra 2.2.1) are helpful in this respect. More specifically, insights from legal anthropologists studying legal pluralism may clarify terminology. For example, de Sousa Santos highlighted the importance of legal hybrids, which are 'legal entities or phenomena that mix different and often contradictory legal orders or cultures, giving rise to new forms of legal meaning and action. ${ }^{58}$ Similarly, in the

53 Pouligny, Chesterman and Schnabel, loc.cit. (note 46), at p. 7.

54 See Penal Reform International (PRI), 'Gacaca Research Report, Rapport 1: Gacaca Jurisdictions and Its Preparations', 2002, available at: www.penalreform.org; Reyntjes, Filip and Vandeginste, Stef, 'Rwanda: An Atypical Transition', in: Skaar, Elin (ed.), Roads To Reconciliation, Lexington Books, Lanham, 2005, pp. 101-127; and Waldorf, Lars, 'Mass Justice for Mass Atrocity: Rethinking Local Justice as Transitional Justice', Temple Law Review, Vol. 79, Spring 2006, pp. 1-87.

$55 \quad$ Huyse and Salter (eds), op.cit. (note 52), p. 203.

56 Huyse, loc.cit. (note 52), at p. 16.

57 See Waldorf, loc.cit. (note 54); and Baines, Erin, 'The Haunting of Alice: Local Approaches to Justice and Reconciliation in Northern Uganda', International Journal of Transitional Justice, Vol. 1, No. 1, 2007, pp. 91-114.

58 De Sousa Santos, Boaventura, 'The Heterogeneous State and Legal Plurality', Law \& Society Review, Vol. 40, No. 1, 2006, pp. 39-71, at p. 46. He also clarifies the dichotomies of official/unofficial, 
context of post-conflict reconstruction, Culbertson and Pouligny demonstrate that local groups 'return to tradition' to solve conflict after mass crime, but also recognise 'that innovation is part of every culture's reality, and that borrowing and grafting ideas from the outside and reshaping old concepts to new experiences are also important local strategies. (...) They should be understood as such and not romanticized.'59

Therefore, debates on cultural diversity in transitional justice should be able to transcend the dichotomy between 'traditional' and 'new, modern'. This would allow a more useful focus on understanding local forms and the logic of social ties, their transformations and the manner in which local actors have tried to survive and understand mass atrocities. ${ }^{60}$ This empirical bottom-up point of view can be compared to the 'vernacularisation/localisation' of human rights. This 'localisation/ vernacularization of transitional justice' questions whether debates on 'traditional' mechanisms in transitional justice should focus as much as they currently do on their strengths and weaknesses, their effectiveness and legitimacy, their potentials and limitations, or even the availability of checks-and-balances. These issues may be top-of-mind from the viewpoint of States, international law and international donors, yet one might ask to what extent these are the concerns of the survivors at the local level. The insights from post-colonial studies on the role of the 'locus of enunciation' are relevant here: the context from which one speaks shapes the knowledge the person produces. ${ }^{61}$ Finally, it is crucial to acknowledge the indivisibility of the local and international dimensions of transitional justice. Merry has emphasised the need to take into account transnational processes to understand and theorise local legal phenomena. ${ }^{62}$ Discussing peace talks in northern Uganda, Baines stated the challenge as that of uncovering 'how local approaches to justice and reconciliation inform and shape international approaches. This might involve adapting aspects of local justice that meet international standards, but will also require that international strategies be transformed to fit local socio-cultural and economic realities. ${ }^{63}$ Indeed, as Goodale

formal/informal and traditional/modern. For example, 'traditional/modern variable relates to the origins and historical duration of law and justice. A form of law is said to be traditional when it is believed to have existed since time immemorial, when it is impossible to identify with any accuracy the moment or the agents of its creation. Conversely, a law is said to be modern when it is believed to have existed for a shorter period of time than the traditional and when its creation can be identified as to time and/or author.'

59 Culbertson, Roberta and Pouligny, Béatrice, 'Re-imagining peace after mass crime: A dialogical exchange between insider and outsider knowledge', in: Pouligny, Chesterman and Schnabel (eds), op.cit. (note 46), pp. 271-287, at p. 272.

60 Pouligny, Chesterman and Schnabel, loc.cit. (note 46), at p. 7.

61 Bhabha, Homi, The Location of Culture, Routlegde, New York, 1994; and Mignolo, Walter, Local Histories/Global Designs. Coloniality, Subaltern Knowledges, and Border Thinking, Princeton University Press, Princeton, 2000.

62 See Merry, 'Transnational Human Rights and Local Activism: Mapping the Middle', loc.cit. (note 19).

63 See Baines, loc.cit. (note 57), at p. 114. 
and Clarke argue, it is not enough to simply counterpose the international or transnational to the local, as the scales of contemporary normative practice are both more interpenetrating and mutually constitutive'. ${ }^{64}$

\subsection{PRACTICE: WHEN THE GLOBAL MEETS THE LOCAL AND VICE VERSA}

It is thus crucial to explore what happens when the global - transitional justice efforts from the State or international actors - meets the local - communities and survivors - and vice versa. A huge knowledge gap remains on the concrete (potential) role of 'traditional' justice systems in dealing with massive human rights violations in different post-conflict contexts. What can be derived at this stage from the slowly growing body of ethnographic field research is that the process of vernacularisation of transitional justice is facing difficult encounters and that the global discourses on justice, reparation, reconciliation and truth seems to overlook what is happening beneath the surface at the local level.

\subsubsection{Difficult Encounter}

Few in-depth studies have examined the encounter between globalised discourses on justice, reconciliation, truth and reparations on the one hand and their appropriation or failure in a specific local and cultural context. The studies that are briefly presented below elucidate that those encounters are accompanied by frictions, short circuits and even clashes between different frames of reference or logics. ${ }^{65}$

Shaw, in her study on truth-telling as practiced in the Truth and Reconciliation Commission (TRC) in Sierra Leone, explores the frictions of engagements that occur when transitional justice mechanisms are implemented in local contexts. ${ }^{66}$ She finds that in addition to the contestation of the content of the memory of the

64 Goodale, Mark and Clarke, Kamari Maxine, 'Introduction: Understanding the Multiplicity of Justice', in: Clarke, Kamari Maxine and Goodale, Mark (eds), Mirrors of Justice. Law and Power in the Post-Conflict War Era, Cambridge University Press, Cambridge, 2010, pp. 1-27, at p. 18.

Other interesting ethnographic research is the work of the anthropologist Alcinda Honwana on traditional healing and local concepts of mental health in post-conflict Mozambique and Angola: Honwana, Alcinda, 'Healing and Social Reintegration in Mozambique and Angola', in: Skaar (ed.), op.cit. (note 54), 2005, pp. 83-100; Green, E. and Honwana, A., Indigenous Healing of WarAffected Children in Africa', The World Bank: I.K., Notes, 1999, World Bank, Washington DC, 1999; and Honwana, Alcinda, 'Healing for Peace: Traditional Healers and Post-War Reconstruction in Southern Mozambique', Journal of Peace Psychology, Vol. 3, No. 3, 1997, pp. 293-305. Other fieldbased studies are of Quinn, Joanna, 'Social Reconstruction in Uganda: the Role of Customary Mechanisms in Transitional Justice', Human Rights Review, Vol. 8, No. 4, 2007, pp. 389-407; and Stovel, Laura, 'There's no bad bush to throw away a bad child: "tradition"-inspired reintegration in post-war Sierra Leone', Journal of Modern African Studies, Vol. 46, No. 2, 2008, pp. 305-324. 
conflict, struggles concern a perceived incommensurability between the redemptive verbal remembering paradigm of the TRC, and the local arts of forgetting. This had implications for processes of personal and national reconstruction. Although the friction between the two different memory projects created in some ways new forms of remembering and forgetting, Shaw states that the TRC was not able to respond to the needs of the survivors.

In another study on the public hearings of the TRC in Sierra Leone, Kelsall argues that in certain circumstances ritual may be more important to reconciliation than truth. ${ }^{67}$ According to his findings, truth was told only partially in cross-examination, and moreover was largely ineffectual. In contrast, the reconciliation ceremony of repentance and forgiveness at the end of a hearing which was based on a multicultural mix of Christian, Islamic and traditional religious forms, had a remarkable impact on the hearings, transforming the atmosphere from one of virtual crisis to one of emotional release and reconciliation.

Similarly, Ingelaere, in his work on the Rwandan Gacaca jurisdictions, argues that a problematic quest for truth causes short-circuits in post-genocide Rwanda. ${ }^{68} \mathrm{He}$ locates one of the frictions in a clash between an imposed model with forensic 'truth'telling as a cornerstone and a socio-political environment mediated by a culture of deceit and dominated by a war victor. In the wake of the genocide a natural process of cohabitation between victims and perpetrators has taken place. According to Ingelaere,

[T] he arrival of the Gacaca and the necessity to speak the 'truth' created an overall 'crisis of transparency', a tension worsening social cohesion and attitudes towards the 'other group' - a crisis due to a clash between an imposed model with forensic 'truth' - telling as cornerstone on the one hand, and different communication principles informed by cultural sensibilities and political circumstances on the other. ${ }^{69}$

Further, in a study on Mayan Q'eqchi' perceptions and aspirations regarding the National Reparations Programme (Programa Nacional de Resarcimiento (PNR)) in Guatemala, Viaene shows that the critiques of Q'eqchi' survivors reveal the underestimation and undervaluation of cultural understanding and conceptions of reparations in the PNR. ${ }^{70}$ Its design clashes with fundamental Q'eqchi' norms and values while its implementation disregards both local and cultural dynamics and realities. For example, as the PNR has been designed and implemented in Spanish,

$67 \quad$ Kelsall, Tim, 'Truth, Lies, Ritual: Preliminary Reflections on the Truth and Reconciliation Commission in Sierra Leone', Human Rights Quarterly, Vol. 27, No. 2, 2005, pp. 361-391.

68 Ingelaere, Bert, "Does the Truth Pass Across the Fire Without Burning?” Locating the Short Circuit in Rwanda's Gacaca Courts', Journal of Modern African Studies, Vol. 47, No. 4, 2009, pp. 507-528.

$69 \quad$ Ibidem, p. 524.

70 Viaene, Lieselotte, 'Life is Priceless: Mayan Q'eqchi' Voices on the Guatemalan National Reparation Program', International Journal of. Transitional Justice, Vol. 4, No. 1, 2010, pp. 4-25. 
the PNR had to translate the key concept resarcimiento or reparation into Q'eqchi' to explain its mission and purpose. However, translating this terminology is not straightforward as this concept does not exist in the Q'eqchi' language. Further, the individual economic compensation, which is its main reparation measure, generates a strong sentiment of guilt amongst the beneficiaries not only towards the deceased relatives, but also toward others who have suffered, but who, for bureaucratic reasons do not obtain compensation. There is also a lack of interest and acknowledgement of resources of Mayan beliefs and practices and the role of traditional leaders and healers in dealing with health issues of survivors.

\subsubsection{Beneath the Surface}

Other empirical studies suggest that at a deeper level, even more fundamental issues arise. Beneath the surface there is a hive of activity which at first and quick sight is invisible.

In the wake of the civil war in Mozambique (1976-1992) the political authorities opted for politico-legal measures to secure impunity for war crimes and gross human rights violations and war survivors were simply advised to forget what happened and to forgive one another. A study on central Mozambique uncovered however the emergence of beliefs and practices concerning magamba spirits. These are spirits of dead soldiers who return to the realm of the living to fight for justice. ${ }^{71}$ Those spirits break with the post-war conspiracies of silence regarding a violent past. According to Igreja and Dias-Lambranca:

In the social spaces that are created in the magamba healing ceremonies, the violence of the past is re-enacted: the grudges, bitterness and discontentment in the hearts of the survivors can be conveyed without the risk of starting a fresh cycle of abuse and violence. They channel negative feelings and restore the dignity of individual war survivors and their families. ${ }^{72}$

In that region, reconciliation is a multidimensional phenomenon and these spirits reveal the multiplicity of reconciliation processes and achievements. They illustrate how survivors managed to develop socio-cultural practices that took the form of restorative justice and reconciliation to deal with the aftermath of the civil war. Honwana in her study of local concepts of mental health in Mozambique and Angola, confirms that '[b]eyond the verbal sphere, an inclusive use of symbols and symbolic

\footnotetext{
$71 \quad$ Igreja, Victor and Dias-Lambranca, Beatrice, 'Restorative justice and the role of magamba spirits in post-civil war Gorongosa, central Mozambique', in: Huyse and Salter (eds), op.cit. (note 52), pp. 61-83.

$72 \quad$ Ibidem, p. 79.
} 
actions can be an equally important road to reconciliation', and that 'reconciliation processes need to be locally driven and "owned". 73

Also in post-conflict Guatemala, impunity of the armed forces for past atrocities persists after 25 years. Viaene's study among the Maya Q'eqchi reveals that, impunity, as defined by international law, is not the end of accountability, nor truth recovery or reparation. Her findings suggest that this can be explained by the Q'eqchi belief in an internal logic of the cosmos in which an invisible spiritual force (q'oqonk), fosters social and spiritual repair at community level. ${ }^{74}$ Q'oqonk is pain or sadness that somebody or something feels for being treated badly/wrongly and that will be converted into a retributive punishment on the causer of the pain or sadness. It occurs when a person deliberately and persistently harms someone or something and does not recognise his transgression nor seek to rehabilitate anyone's dignity. Q'oqonk affected specific perpetrators who caused terror and fear in the communities. Some of them died in strange circumstances, while others were struck by disability, poverty and dependency on others. The internal logic of the cosmos through an invisible force put them in a shameful situation and creates an invisible space in which the perpetrator can reintegrate into communal life through which victims are acknowledged for their pain and suffering. This indicates an extension of q'oqonk to situations where an external power, the army, created a space wherein certain people deliberately and persistently harmed others. The presence of q'oqonk exposes the fact that the suffering or dead exceeded their positions and helps to uncover the truth and wrongdoing. It also has a reparative effect because survivors receive recognition of their pain and harms. An invisible space is created through which perpetrators reintegrate into the community, paving the way for reconciliation among survivors. Q'oqonk lifts the problem to the community level. Once somebody is suffering qoqonk it has a retributive and restorative effect on the person, the family and the community. ${ }^{75}$

It is worth clarifying that neither the magamba spirits nor q'oqonk should be been seen as a response to the failure of State institutions to provide accountability measures, but rather as 'well-established local tradition(s) of settling accounts with histories of individual and collective violence. ${ }^{76}$ It is clear that survivors do not wait until the formal justice system is rebuilt and/or interventions of national and international actors are implemented to start a process of reshaping social norms, practices and relationships and of finding a new modus vivendi. Furthermore, in both

\footnotetext{
73 Honwana, 'Healing and Social Reintegration in Mozambique and Angola', loc.cit. (note 65), at p. 98.

74 Viaene, Lieselotte, "The internal logic of the cosmos as "justice" and "reconciliation". Maya Q'eqchi' perceptions from post-conflict Guatemala', Critique of Anthropology, Vol. 30, No. 3, 2010 (forthcoming).

75 Idem.

76 Igreja and Dias-Lambranca, loc.cit. (note 71), at p. 81.
} 
studies, the authors warn for manipulation and politicisation of those phenomena, as justifications of the ruling impunity. ${ }^{77}$

Both studies suggest that there are multiple ways of understanding justice, reparation, reconciliation and truth. They also affirm what Theidon stated in her study of local justice practices in rural post-war Peru:

[T]ransitional justice is not the monopoly of international tribunals or of states: communities also mobilize the ritual and symbolic elements of these transitional processes to deal with the deep cleavages left - or accentuated - by civil conflicts. ${ }^{78}$

\section{TOWARD INCLUSIVE TRANSITIONAL JUSTICE}

Several conclusions can be drawn from the above presented exploration of the comparability of the universality debate in human rights and the cultural challenges to the transitional justice paradigm in the field. They relate to the international perspective on transitional justice, to its implementation at the national level, and to further research in this field.

\subsection{THE INTERNATIONAL PERSPECTIVE}

Claims for cultural diversity and localisation need not be an obstacle to the ongoing development of an 'international law of transitional justice'. Drawing lessons from the universality-relativism debate, the starting point should be that universal standards can and should accommodate diversity and be responsive to local realities. Instead of meeting cultural arguments with suspicion, they should be taken seriously. At the same time, a double caution is warranted. One concerns the need to avoid incorrect simplistic notions of culture or tradition. The other relates to the risk of abuse of cultural arguments in international relations by governments attempting to cover up their shortcomings in dealing with the past. A crucial factor avoiding both risks is the need to give a central place to the insider perspectives of survivors. In line with developments in the area of indigenous rights ${ }^{79}$ and the right to development, ${ }^{80}$ a global normative framework on transitional justice needs to emphasise the participation rights of the people who are directly concerned. Respecting participation rights ties

77 Idem; and Viaene, loc.cit. (note 74).

78 Theidon, Kimberly, 'Justice in Transition: The Micropolitics of Reconciliation in Postwar Peru', Journal of Conflict Resolution, Vol. 50, No. 3, 2006, pp. 433-457, at p. 436.

79 See ILO 169 Indigenous and Tribal Peoples Convention, 27 June 1989. United Nations Declaration on the Rights of Indigenous Peoples, General Assembly Resolution, UN Doc. A/Res/61/295, 13 September 2007.

80 United Nations Declaration on the Right to Development: Resolution Adopted by the General Assembly, UN Doc. A/Res/41/128, 4 December 1986. 
in with the need for international dialogue - including the choice of representative participants in that dialogue acknowledging the diversity among survivors' voices.

Unfamiliar discourses and practices - including spiritual phenomena - and Western discomfort about them need not be an obstacle. The existence of multiple ways of understanding the driving goals of transitional justice, located in different philosophical, epistemological and ontological frames of reference, is a reality that has to be accepted. Here, a distinction between 'thick' and 'thin' accounts of transitional justice appears crucial to understand how optimal integration of local and global views can take shape. International norms and discourse concern a thin version of transitional justice, which is 'thickened' in local cultural contexts. Philosophical and ontological foundations as well as spiritual dimensions concern the thick versions, whereas the thin norms rest on an overlapping consensus. As norms are drafted, room for contextual flexibility should be explicitly provided for. In the process of demarcating a margin of flexibility, its limits should also be made clear. The growing experience of national and international human rights monitoring bodies in this field is a useful resource in this process.

A number of lessons can also be drawn from the current wave of interest among scholars, practitioners and external actors in the role and potential of local and cultural practices and attitudes for future transitional justice interventions. ${ }^{81}$

First, empirical data from different regions reveal difficulties caused by the 'localisation/vernacularisation of transitional justice' or the interplay between the globalised discourses on justice, reconciliation, truth and reparation with local and cultural practices and norms. Moreover, the global level seems to overlook the complexities of what is happening beneath the surface.

Further, there appear to be several risks. One is the risk of biased restriction. It implies that outsider efforts to deal with the legacy of mass atrocities are inclined to make room more easily for local and cultural practices and attitudes that are visible, understandable and manageable to them - 'mechanisms' rather than worldviews. Hence the risk of oversimplification through neglect of the underlying profound and complex cultural logic or frame of reference is real. Next is the risk of essentialism. When initiatives are taken that do not rely on in-depth studies, particular cultural norms and values are easily generalised and promoted as 'the' norms and values of a certain culture or society. This may happen when attractive local proverbs are converted into slogans and used in campaigns to promote reconciliation with the premise of being 'culturally sensitive'. However, disconnecting those proverbs from their deeper local cultural logic creates a superficial 'cultural sensitivity' and ignores the complex, fluid and hybrid character of culture. Another risk is to simplify linguistic tangles and perceive them a as consequence of insufficient understanding of local languages and oral traditions. However, linguistic tangles can indicate tensions between different

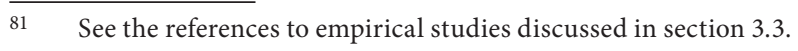


cultural understandings of key concepts of transitional justice. ${ }^{82}$ Finally there is the risk of fixation. This is well-known among legal anthropologists: when inherently dynamic traditions are institutionalised, they become fixed and therefore altered. The complexities and particularities of local and cultural practices and norms come under threat when they are converted into another tool of the transitional justice toolbox.

\subsection{THE NATIONAL PERSPECTIVE}

While examples in this article were drawn both from Sub-Saharan Africa and from Latin America, it is worth remarking that there are important differences between the continents with respect to the role of local and cultural practices and attitudes. In Latin America, the debate concerns the collective rights of indigenous peoples. In Sub-Saharan Africa, on the other hand, this is not in the first place a minority issue as the coexistence of 'Western' and customary law and authorities - whether institutionalised or de facto - affects the entire population.

To the extent that societies are internally diverse, the above recommendations relating to the international level are relevant on the national level as well. In particular, it is both desirable and feasible to draft transitional justice norms and policies in a way that makes room for diversity. This implies in the first place a need for substantial dialogue and real participation: the ideas and expectations of survivors are to be taken seriously. Any national transitional justice policy should address local dynamics of social reconstruction in addition to nation-wide dynamics.

In addition to first-hand accounts of survivors, there appears to be a useful role for experts - in the first place cultural and legal anthropologists - in the drafting of transitional justice policies. In particular, they can help to identify and translate cultural meanings and to advise on how to incorporate culture-based views and expectations into policy. Moreover, the involvement of independent experts can protect against power games by traditional authorities and against the manipulation of tradition for political purposes. An example of good practice in the mobilisation of legal anthropological expertise to determine appropriate remedies in an indigenous context, is the Escué Zapata Case of the Inter-American Court of Human Rights,

$82 \quad$ For example Lesly Dwyer and Degung Santikarma show in their study on mass violence in Bali that there are no terms in the Balinese language that correspond to 'forgiveness', 'amnesty' and 'witnessing' embedded in the models of truth-telling and reconciliation. Dwyer, Lesly and Santikarna, Degung, 'Speaking from the shadows: Memory and mass violence in Bali', in: Pouligny, Chesterman and Schnabel (eds), op.cit. (note 46), pp. 190-214, at p. 197. Similarly, Tim Allen explains in his research on northern Uganda that in the Lwo language "ideas about of "amnesty", "forgiveness", "reconciliation" and the setting aside of punitive judgment are not conceptually distinct. Rather, the concept timo-kica can be used for all of them. Therefore, talk of "forgiveness" may not mean what it suggests in English.' In: Allen, Tim, Trial Justice. The International Criminal Court and the Lord's Resistance Army, Zed Books, London, 2006, p. 131. 
in which anthropologists delivered an expert opinions that clearly inspired the judgment. ${ }^{83}$

\subsection{THE ACADEMIC PERSPECTIVE}

Successful transitional justice policies must adopt a holistic approach. The same applies to research on transitional justice. The questions that are faced today in the transitional justice field have to some extent already been answered in other disciplines. Hence a targeted effort to collect the insight of neighbouring fields - such as legal anthropology and human rights law - can avoid the reinvention of the wheel.

The discussions above have revealed the crucial need for in-depth cultural knowledge and to excavate the complexity of local social and political realities in which this knowledge is embedded. Yet there is a shortness of ethnographic data in this area. The current trend to use population based surveys in transitional justice ensures a broad scope yet fails to explore the deeper cultural logics in which needs, perceptions and attitudes are embedded. The development of appropriate methodologies combining breadth and depth and drawing strength from the complementarity of quantitative and qualitative research methods would allow to uncover and understand the complexity in the field.

To the extent that ethnographic field research is used, the experience of the authors is that it is advisable to use multiple data collection techniques or methodological triangulation to achieve an in-depth understanding of local and cultural complexities of post-conflict processes. This implies that participant observation is complemented with informal interviews, as well as focus group discussions and even ethnolinguistic studies when this is necessary to disentangle language knots. Language tangles are not merely a consequence of insufficient understanding of local languages and oral traditions. Close scrutiny of the semantic logics of terms related to justice, reconciliation, truth and reparation can open windows to cultural understandings that are beneath the visible surface.

83 Escué Zapata vs Colombia, supra note 7. The Court referred to the expert report of Dr Sanchez when it stated that for the Paez people the loss of this leader meant 'dismemberment and harm to the integrity of the collective; frustration due to the all of the trust deposited in him to help them achieve a good life; and feelings of loss due to the collective effort undertaken with the support of his [C]ommunity to be able to carry out his mission as a special person' (para. 124). Moreover, the Court recognised the spiritual and moral repercussions on family members of the four-year wait for the State to turn over the remains of the victim, stating that in accordance with Paez culture 'once a Nasa child is born, the umbilical cord is planted in the Mother Earth (...) in order to germinate life. Now, when he dies, we also plant him, as opposed to burying him, so life will be there. But to take him away is disrespectful of the culture, of Mother Earth. Taking him from his bosom is like cutting out the womb of the woman who saw him conceive, procreate, and grow. It is a considerable cultural affectation and creates deharmonization and decontrol of the territory' (para. 153 - quote from testimony). 
Transitional justice processes are to be seen as transnational. It is therefore necessary to investigate not only what happens when the global meets the local, but also what happens with the local when meeting the global. An interesting question in researching the process of 'localisation/vernacularisation of transitional justice' is to what extent and how (inter)national legalistic discourses of transitional justice penetrate and reshape local and cultural views embedded in normative systems which deviate strongly from international law discourses. For example in Guatemala, it is remarkable that the demand for justice seems significantly weaker among the Maya Q'eqchi' compared to other regions or Mayan groups such as the Maya Achi of Rabinal. ${ }^{84}$ More research is needed to reveal whether this is related to the specificities of the Q'eqchi' cosmovision or rather to the historically lower presence in the Q'eqchi' region of human rights organisations advocating justice. Therefore, in a broader context, attention should also be paid to the role of what Goodale and Clarke call 'moral agents', ${ }^{85}$ such as peasant intellectuals, indigenous leaders or local human rights activists who drive the process of vernacularisation.

\subsection{CONCLUSION}

Countries recovering from authoritarian regimes and gross human rights violations are likely to use the language of human rights and of transitional justice to help rebuild their fragmented societies. The emerging paradigm of transitional justice is not only undergoing a maturation process in which it tends to look closer at what happens at the grassroots, but it also tends toward a new transnational normative system. One of the challenges of the transitional justice field is the reality of local and cultural complexities of post-conflict processes. Insights and lessons learned from related fields such as human rights law and legal anthropology can usefully inform current debates on the use of 'traditional/local' approaches in transitional justice interventions. Many questions remain about the optimal integration of local and cultural practices and attitudes into transitional justice initiatives. However, the main lesson to date is that international and national actors should be cautious with converting those local and cultural practices into another tool of the transitional justice toolbox. A more fruitful approach for both practitioners and scholars is to focus more on the process of vernacularization of transitional justice efforts in search for a truly inclusive transitional justice paradigm.

$84 \quad$ Survivors of the 1982 Río Negro massacre near Rabinal filed criminal complaints against the perpetrators before the court of Salamá. In 2008, six accused were sentenced to 780 years' imprisonment. Moreover, survivors of the Plan de Sanchez massacre near Rabinal received compensation from the State as a result of two judgments of the Inter-American Court of Human Rights in 2004. See Plan de Sánchez Massacre vs Guatemala, supra note 7. 